\title{
Martin Trybus, Marta Andrecka, Favouring Small and Medium Sized Enterprises with Directive 2014/24/EU? (Czy regulacje dyrektywy 2014/24 UE faworyzują małe i średnie przedsiębiorstwa?), „European \\ Procurement \& Public Private Partnership Law Review" 2017, vol. 12, iss. 3, s. 224-238, DOI: https://doi.org/10.21552/epppl/2017/3/6
}

Pracom legislacyjnym nad dyrektywą 2014/24/UE - będącą jednym z filarów unijnego prawa zamówień publicznych - towarzyszyły wątpliwości dotyczące kierunków zmian, jakie miały nastąpić $\mathrm{w}$ wyniku ustanowienia projektowanych zmian normatywnych. Ich kresu nie przyniosło ustanowienie tego aktu normatywnego oraz implementowanie przepisów w nim zawartych do porządków prawnych poszczególnych krajów członkowskich. Obszarem wzmożonych wątpliwości są regulacje ustanowione z zamysłem zwiększenia poziomu instrumentalizacji poszczególnych polityk zamówieniowych, w tym dotyczącej wspierania podmiotów z sektora MŚP (postrzeganej również jako element polityki prospołecznej). Pomimo niekwestionowania zasadności argumentów przemawiających za realizacją tzw. celów drugorzędnych (drugoplanowych) - do których autorzy zaliczają wspieranie podmiotów sektora MŚP - pojawiają się wątpliwości, czy regulacje sprzyjające ich realizacji nie kolidują $z$ celami pierwotnymi, $t$ j. obejmującymi zapewnienie władzy publicznej niezbędnych towarów i usług nabywanych w sposób ekonomicznie opłacalny i z poszanowaniem zasad konkurencji, równego traktowania wykonawców i jawności. Wątpliwości takie odnoszone są m.in. do regulacji dyrektywy 2014/24/UE dotyczących:

1. podziału zamówień publicznych na części. Kwestii tej poświęcony został art. 46 dyrektywy 2014/24/UE;

2. wykorzystania Jednolitego Europejskiego Dokumentu Zamówienia, który normowany jest wieloma regulacjami dyrektywy 2014/24/UE, albowiem jest to oświadczenie własne wstępnie poświadczające spełnianie przez wykonawcę warunków udziału w postępowaniu oraz kryteriów selekcji oraz niepodleganie wykluczeniu z postępowania;

3. ograniczenia swobody zamawiających w określeniu warunków udziału w postępowaniu (kryteriów kwalifikacji) dotyczących sytuacji ekonomicznej i finansowej wykonawców w zakresie, w jakim dotyczą one minimalnych rocznych obrotów (zasadniczo, skonstruowany przez zamawiającego warunek odwołujący się do obrotów nie może przekraczać maksymalnie dwukrotności szacunkowej wartości zamówienia) - art. 58 ust. 3 dyrektywy 2014/24/UE;

4. uiszczania przez zamawiających bezpośrednich płatności na rzecz podwykonawców. Materia ta uregulowana jest w art. 71 ust. 3 dyrektywy 2014/24/UE. 
Autorzy artykułu rozważaja, czy poszczególne rozwiązania prawne spośród wyżej wymienionych można zakwalifikować jako faworyzujące podmioty sektora MŚP w trakcie ubiegania się o uzyskanie i podczas realizacji zamówień publicznych. W tym celu podejmują próbę interpretacji przepisów dyrektywy 2014/24/ UE dotyczących wskazanych kwestii i odnoszą konsekwencje obowiązywania tych regulacji do przyjętego miernika oceny, za pomocą którego przeprowadzają "test faworyzowania". Polega on na przyjęciu, że środkami faworyzującymi są wyłącznie te, które nakierowane są na wsparcie podmiotów MŚP w sposób kolidujący z podstawowymi elementami konstruującymi unijny model udzielania zamówień publicznych, którymi są: konkurencja, zapobieganie dyskryminacji wykonawców oraz ekonomiczna opłacalność procesów nabywczych. Przyjęcie wskazanego miernika umożliwia odseparowanie od siebie rozwiązań, które chociaż nastawione są na promowanie podmiotów przynależących do zbiorowości MŚP (co jest niewątpliwie trwałym celem polityki obowiązującej w obszarze unijnych zamówień publicznych - zob. m.in. motyw 14 dyrektywy 2014/24/UE), nie faworyzują ich jako kategorii uczestników rynku zamówień publicznych. Jako przykład autorzy podaja, że zastosowanie wskazanego miernika skutkuje uznaniem za faworyzujące podmioty sektora MŚP przepisów przyjętych w systemie amerykańskim, określających minimalny poziom udziału podmiotów z sektora MŚP w zamówieniach publicznych. Bezpośrednią konsekwencją istnienia tego mechanizmu prawnego jest ograniczenie udziału podmiotów spoza sektora MŚP w uzyskiwaniu zamówień publicznych lub utrudnienie im udziału w procesie ubiegania się o zamówienia publiczne. Powyższe w ocenie autorów odróżnia rozwiązania amerykańskie od przyjętych w dyrektywie 2014/24/UE, które określić można mianem "przyjaznych dla MŚP”, "ułatwiających dostęp MŚP” poprzez eliminowanie barier, jakie napotykają podmioty sektora MŚP w ubieganiu się i realizacji zamówień publicznych. Celem tych rozwiązań nie jest uprzywilejowanie pozycji podmiotów przynależących do tej kategorii członków społeczności zamówień publicznych, lecz zwiększenie ogólnego poziomu konkurencji. W konsekwencji przyjęte rozwiązania nie kolidują z celami pierwszoplanowymi, lecz je uzupełniają i wspierają. Promowanie podmiotów przynależących do sektora MŚP, będącego jednym z elementów zrównoważonych zamówień publicznych, stanowi wartość dodaną reformy unijnego prawa zamówień publicznych przeprowadzonej w 2014 r. Autorzy, konkludując, zastrzegaja, że stopień, w jakim przyjęte rozwiązania pozwolą na osiągnięcie zamierzonych celów (zwiększenia udziału MŚP w partycypacji w korzyściach płynących z rynku zamówień publicznych), jest uzależniony od wielu czynników nieograniczających się wyłącznie do kwestii normatywnych. 